\title{
Is There a Relation Between the Level of Development and Government Systems? An Overview on Latin America, Euroasia and the East Asia
}

\author{
Ph. D. Candidate Yaşar Pınar Özmen (Gazi University, Turkey) \\ Prof. Dr. Gonca Bayraktar Durgun (Gazi University, Turkey)
}

\begin{abstract}
The purpose of this paper is to study if a meaningful relation can be argued between government systems and the level of development by using main socioeconomic indicators. The systems of government in the Latin American, Eurasian and the East Asian countries are classified as presidentialism, president- parliamentary, premier - presidential and parliamentarism. For the aim of the paper, the countries are selected according to the two criteria, population and income. On the basis of 1995-2013 annual data, the time series are obtained from the international organizations and research institutes. The panel data analysis covers socioeconomic indicators (population, gross domestic product per capita, unemployment rate) and some composite indicators (human development index and democracy scores).
\end{abstract}

\section{Introduction}

The debate on government systems flared up in the aftermath of the dissolution of Yugoslavia and of the Soviet Union. In the early 1990 s, the argument that there was a qualitative difference in terms of democratic persistence and consolidation between the parliamentary system and the presidential system was the focal point of the debate. During the same period, the institutional structures of democratic governments replacing the military dictatorships in Latin America and Asia were a particular area of research for political science. The comparison effort of the new period to that of military coups or of the earlier interruption of democratic order has been widespread in academic studies. In that period where the pessimistic view for the presidential system was prevalent, the thesis as "the supremacy of parliamentarism to presidentialism" suggested by Linz (1990) was widespreadly supported. This viewpoint was very influential for later debates. In this context, the fragility of democracies and the threat of turning back to authoritarianism in the countries with presidential systems excluding United States of America were particularly often explained in the frame of "the perils of presidentialism". Low level of economic development was emphasized as a factor increasing fragility. However, the situation changed rapidly after 1994 with the end of hyper-inflation in the countries in question and revealed more optimistic comments about governability related to presidentialism. Meanwhile, considerable amounts of data were revealed which could not verify empirically the thesis of perils of presidentialism prevailing in the previous period.

In this study, the relation of government systems with development and democracy is investigated concerning Latin American, Eurasian and the East Asian countries. The study reveals that there is no strong evidence about superiority of any government system according to development and democracy indicators. While no significant relationship between socio-economic development and government systems is established, however it can be argued that the link between government system and democracy is significant. The variation of decision making process in each category prevents making comparisons with general definitive classifications. In other respects, authoritarian and imperial history of country, management of natural resources and correspondingly sociocultural environment are variables which are mostly difficult to measure.

\section{Political Systems, Development and Government Systems}

The comparison of political systems has been a research theme that can be traced back to Aristotle's classical work. The oldest and most widely discussed subject is related to the classification of systems in political research. However, the relationship between economic development and political systems is also a very common issue. Especially researches related to structural changes in political systems resulting in the formation of new states in the world have been at the center of comparative politics. While the number of democratic countries has increased since the early 1990s, accordingly, the comparisons of political systems, government systems and other related institutional systems have been widespread. More specifically, the comparison studies between the authoritarian/totalitarian political systems and democratic systems in terms of socioeconomic indicators have concentrated.

In these researches dealing with the relation between democracy and development, the focal point has been about which one of them has preceded the other. Accordingly, three different views can be generalized from those researches: (a) democracy provides favorable conditions for economic development, (b) demand for democracy only emerges after a certain degree of development is reached, (c) there is not a direct relation between the two. Thus, on the one hand, it is argued that democracy, compared to the more authoritarian systems, contributes more to economic development and due to this reason it is a prerequisite. On the other hand, studies are available rooted 
in the argument that democracy is not a prerequisite for economic growth. Even the latter argues that autocratic systems affect economic development in a more positive way. There are studies that draw attention to the fact that development does not directly cause democratization (or authoritarianization) of a country. Considering the studies pointed out that there is not a clear relationship between qualifications of government systems and economic development, it is clearly revealed that relations among presumptions, assumptions and data should be handled cautiously for the purposes of the researcher.

As one of the works on this subject, Lipset (1959), Cutright (1963) found a positive linear relationship between democracy and development. Lipset (1959: 56), one of the modernization theorists argue that democracy can only be sustained in countries with high economic development. Neubauer (1967), Jackman (1973) identified a curvilinear relationship; democratic performance increased and then leveled off at a certain level of economic development. Huntington (1968), Linz (1978), Bollen (1979), Przeworski \& Limongi (1997), Gasiorowski (1995), Haggart \& Kaufman (1995), Przeworski et al (1996), Gasiorowski \& Power (1998) are other researchers claim that higher levels of economic development and positive economic performance enable democracies to endure (Bernhard et al, 2001). Huntington (1968) and Olson (1982) suggested that rapid economic growth could also destabilize democracy for the reason that accelerated growth could produce social upheaval by disrupting traditional social relations (Bernhard et al, 2001).

Kurzman, Werum and Burkhart summarize the findings of the 47 quantitative studies applied between 1963 and 1997 as for the relationship between growth and democracy. According to this, 19 studies identified a positive relationship, 6 studies found negative relationship and 10 studies could not find a significant relationship between growth and democracy. Depending on the models used and sample coverage, 7 studies have a positive and insignificant relationship, and 2 studies have negative and insignificant relationships. Both positive and negative mixed results were achieved in two studies, and an inverted U-shaped relationship was achieved in a research (as cited in Doğan, 2005). Przeworski et al (2000), analyze a large cross-section time-series dataset, encompassing a time span from 1950 to 1990 with 135 countries and they conclude that development does not cause to the emergence of democracy, it merely helps democracy endure once it is established.

Przeworski showed in his work (2004) that the relation between economic development and political system is more complex. Among the 135 countries considered, forty-four countries remained under dictatorships during which they were independent between 1950 and 1999, while thirty-four countries had been democratic during this entire period. Twenty-nine countries experienced one regime transition: two from democracy to dictatorship, twenty-seven from dictatorship to democracy. Sixteen countries experienced at least two transitions, e.g. Argentina, had eight. He argues that democracies are unlikely to be established in poor countries, and less likely if a dictatorship exists in a country with a high level of per capita income. He points out that the income levels at which democracies emerge vary widely and there is not any development level for a dictatorship to die.

Relating the relationship between political modernization and development, as mentioned above, since the 1990 s, the studies focused on the relationship between government systems and the continuity or fragility of democracy. In this focal point they have also reached different conclusions. The concept of government system represents the entire rules and institutions related to distribution and arrangement of the state's legislative, executive and judicial powers. Government system classification is specifically based on the relationship between the legislative and executive power in democratic systems, with the assumption that judiciary should be independent. Since legislative and executive powers are as well apart from each other according to the principle of the separation of power; presidential, semi-presidential and parliamentary system has emerged as a classic government classification systems. The presidential system of the United States, the semi-presidential system of France and the parliamentary system of the United Kingdom are mostly used for the basis of typology for comparative political systems.

However, different practices have been observed that were not in accordance with the classical typologies since the late 1980s with emergence of new democratic systems. It marked a new era of new democratic governments, whereby many countries had to make difficult constitutional choices about which form of government to adopt. They preferred the new hybrid systems combining the various features of different systems (Yücel, 2003; Elgie, 2005; Shugart, 2005; Elgie \& Schleiter, 2009). The semi-presidential system is decomposed as different three subclasses between pure presidential and pure parliamentary system in both ends. This distinction actually was first made by Shugart and Carey (1992).

However, this distinction for semi-presidential system has not always been appreciated in the literature and criticized on various terms (Shugart, 2005). It is under debate due to differences between structure of formal institutional relations and implementation. Elgie (1999), provides a minimalist description for semipresidentialism; where a constitution includes a popularly elected fixed-term president and a prime minister and cabinet who are collectively responsible to the legislature. Accordingly, three types of semi-presidential system are described: Semi-presidential system which is very close to presidential system, semi-presidential system with ceremonial (symbolic) president, and semi-presidential system that balanced the power of the prime minister and president. As of 2013, Russia, Azerbaijan, Belarus, Kazakhstan, Ukraine and Peru have systems very close to presidential systems. Bulgaria, Portugal and Slovenia can be given as examples of symbolic presidential system. 
France, Poland and Croatia are examples for the third group of semi-presidential system. According to Elgie and Schleiter, there seem to be two reasons for constitution drafters to choose semi-presidentialism: a desire for constitutional rules that require power-sharing, and the desire for flexibility through presidential action. They emphasize that the direction towards investing the presidency with extensive powers appear to have a price in terms of democratic survival (Elgie \& Schleiter 2009).

For the purposes of this study the typology dividing government systems into five classes according to maximalist approach is used. This grounds the criteria on the election of president and effectiveness provided by the legal and political power (Shugart \& Carey, 1992). These categories are listed below in descending order according to the president's influence on executive power:

- Pure presidential system: There is a directly elected (or popularly elected) president for fixed-term. President is also the head of executive branch and has too wide power. Cabinet members are not collectively responsible to the legislature. The secretaries serve as ministers subject to the president. The president has the power to appoint and dismiss cabinet members. The United States are typical example of this system.

- President-parliamentarism: The president is popularly elected. The president has the power to dissolve parliament and to dismiss government. Both the prime minister and cabinet are collectively responsible to both the legislature and the president ("dual accountability", Shugart \&Carey, 1992). The parliament may dissolve the government and this is the key difference from pure presidential system. The term "Super-presidential" for this system was first used by Fisher in an article he wrote in 1997 for Russia (Gönenç, 2007). While German Weimar Republic provides a classic example, the current Russian Federation's system is a typical case.

- Premier presidential (semi presidential): The popularly elected president has important powers including dissolving the parliament, but cannot make a restriction on government. The president cannot dismiss the cabinet. The prime minister and cabinet are collectively responsible solely to the legislature.

- Parliamentary with president: A popularly elected president is accompanied by parliamentary system. The fact that popularly elected president provides a political program for voters constitutes the basis of the difference from the parliamentary system.

- Pure parliamentary system: There is a parliament which is determined by voters' choice and the dynamics of the electoral system where the prime minister and cabinet are collectively responsible to the legislature. The government is determined by the parliament and may be dismissed. The president is the head of state and mostly ceremonial without a political program. The United Kingdom parliamentary system is the most authentic example.

In the study, the classification of government systems is based on the typology of Shugart and Carey (1992) as mentioned above, but "the parliamentary with president" category was added to semi-presidential systems according to Elgie's (2015) remarks on it.

Another classification was also developed by Siaroff (2003) on the grounds of incompetence of classical classifications. In this classification, eight categories are defined according to dispositional combinations. The key initial distinction involves whether the head of state is also the sole head of government. And the answer of the questions designates the categories: Is the head of state popularly elected or not? Is the head of government (who may also be the head of state) accountable to the legislature and thus removable by a vote of non-confidence? Siaroff (2003) wants to show that the categories of presidential, parliamentary and semi-presidential systems can certainly all be defined conceptually, but definitions are of varying utility in telling us about the powers of presidents.

Government systems are compared according to variables of stability and development level of countries. Linz $(1978,1990)$ bases his argument about the superiority of parliamentary systems over presidential systems with respect to democratic stability. The argument of instability of the presidential systems have a lot of supporters following Linz, e.g. Stepan \& Skach (1993), Jones (1995: 34), Mainwaring \& Scully (1995). In their study about democracy and development, Prezeworski et al. (2000) point out that parliamentary democracies are much more likely to survive than presidential ones. Many researchers assert that parliamentary systems have more centralized decision-making process, incentives for negotiations and coalition formations these inferences have become a common view in the literature.

On the other hand, while comparative studies regarding the government systems continue, the criticisms relating to these kinds of comparisons have also been made. In a similar manner to Siaroff (2003), Cheibub and Limongi (2002) reconsider general descriptions of government forms and state that conceptual categories cannot reflect the diversity in the practices. Accordingly, the main difference between presidential and parliamentary systems lies in the way the decision-making process is organized. But the generalized conceptual definitions cannot provide enough information about the sustainability of the system. "Parliamentary systems do not operate under a "majoritarian imperative"; deadlock is not as frequent as supposed under presidentialism and is not absent from parliamentarism; coalition governments are not foreign to presidential systems and emerge for the same reasons as they do in parliamentary systems; decision making is not always centralized under parliamentarism and is not always decentralized under presidentialism" (Cheibub \& Limongi, 2002). Bernhard et al. (2001) likewise suggest that in and of themselves institutions do not determine democratic survival. The impact of institutions on durability 
varies according to economic performance depending upon the way they concentrate or disperse decision-making power. In their model, parliamentarism and presidentialism have an effect on survival in combination with different party systems due to the extent that they concentrate or disperse decision-making power. Consequently, previous findings, inferences and generalizations based on the conceptual definitions need to be considered very carefully.

\section{The Scope of the Research and Methodology}

In the study, 53 countries are selected from Latin America, Eurasia and Pacific regions according to the population and income criteria. Former Soviet Union, Yugoslavia and independent countries of former Eastern Bloc, Latin America and Asia are in the scope. Majority of these countries was ruled by totalitarian and authoritarian regimes in recent history and started to democratization in 1970s. Jamaica and Papua New Guinea achieved independence from dominating countries in the same period. Costa Rica has also been included in the study as Latin America's oldest democracy.

53 countries in the scope of the research are shown below in Table 1 (The countries have been covered with more than two million population and GDP per capita between 1,500 and 20,000 US dollars. Only exceptions, Estonia and Montenegro (population less than two million), Kyrgyz Republic (GDP per capita less than 1,500 US dollars), Slovenia and South Korea (GDP per capita more than 20,000 US dollars) are taken into the scope for the sake of regional completeness in comparison)

\begin{tabular}{|c|c|c|}
\hline Presidential & Semi-presidential & Parliamentary \\
\hline $\begin{array}{l}\text { Latin America \& Caribbean } \\
\text { Argentina } \\
\text { Bolivia } \\
\text { Brazil } \\
\text { Chile } \\
\text { Colombia } \\
\text { Costa Rica } \\
\text { Dominican Republic } \\
\text { Ecuador } \\
\text { El Salvador } \\
\text { Guatemala } \\
\text { Honduras } \\
\text { Mexico } \\
\text { Nicaragua } \\
\text { Panama } \\
\text { Paraguay } \\
\text { Uruguay } \\
\text { Venezuela, RB } \\
\text { East Asia \& Pacific } \\
\text { Indonesia } \\
\text { Philippines } \\
\text { South Korea } \\
\text { Europe \& Central Asia } \\
\text { Uzbekistan } \\
\text { Turkmenistan }\end{array}$ & $\begin{array}{l}\text { East Asia \& Pacific } \\
\text { Mongolia } \\
\text { Europe \& Central Asia } \\
\text { Azerbaijan }(*) \\
\text { Armenia } \\
\text { Belarus (*) } \\
\text { Bulgaria } \\
\text { Croatia } \\
\text { Czech Republic } \\
\text { Georgia } \\
\text { Kazakhstan }(*) \\
\text { Kyrgyz Republic } \\
\text { Lithuania } \\
\text { Macedonia, FYR } \\
\text { Montenegro } \\
\text { Poland } \\
\text { Romania } \\
\text { Russian Federation }(*) \\
\text { Serbia } \\
\text { Slovak Republic } \\
\text { Slovenia } \\
\text { Ukraine }(*)\end{array}$ & $\begin{array}{l}\text { East Asia \& Pacific } \\
\text { Malaysia } \\
\text { Papua New Guinea } \\
\text { Thailand } \\
\text { Europe \& Central Asia } \\
\text { Albania } \\
\text { Estonia } \\
\text { Hungary } \\
\text { Latvia } \\
\text { Moldova } \\
\text { Turkey }\end{array}$ \\
\hline
\end{tabular}

Table 1. Countries by Government Systems

The countries with $(*)$ correspond president-parliamentary systems in the classification of Shugart and Carey (1992). Elgie (2015) classified them as semi presidential systems.

Countries are grouped according to classic government system categories in Table 1. Azerbaijan, Belarus, Kazakhstan, Peru, the Russian Federation and Ukraine are categorized as president-parliamentary in keeping with classification of Shugart and Carey (1992). Government system changes in countries are also taken into account in the period of 1995-2013. The implementation periods of systems by countries are as follows: "Presidentparliamentary" for 1995-2004, "Semi presidential" for 2005-2013 in Armenia; "President-parliamentary" for 
1995-1999, "Parliamentary" for 2000-2013 in Croatia; "Semi presidential" for 1995-2000, "Parliamentary" for 2001-2013 in Moldova; "President-parliamentary" for 1996-2006 and for 2011-2013, "Parliamentary" for 20072011 in Ukraine (Elgie, 2015).

Two statistical analysis techniques were performed for comparison. Firstly, principal component analysis was used with the average of 1995-2013 annual data. Panel data analysis for 53 countries in the period 1995-2013 has also been performed in order to examine the relationship between government systems and socioeconomic indicators. Information about the data used in the analysis is in Table 2 below.

\begin{tabular}{|c|c|c|c|}
\hline Variable & Definition & Scale & Data Source \\
\hline Government system & $\begin{array}{l}\text { (1) presidential, (2) president-parliamentary, (3) semi- } \\
\text { presidential, (4) parliamentary }\end{array}$ & Categorical & $\begin{array}{l}\text { Elgie (2015), } \\
\text { Shugart \& } \\
\text { Carey }(1992)\end{array}$ \\
\hline Population $(\log )$ & Annual population data & Ratio & World Bank \\
\hline GDP (constant) $(\log )$ & Data are in constant 2005 U.S. dollars & Ratio & World Bank \\
\hline GDP per capita $(\log )$ & Current GDP per capita in US Dollars. & Ratio & World Bank \\
\hline $\begin{array}{l}\text { Life expectancy at } \\
\text { birth }(\log )\end{array}$ & $\begin{array}{l}\text { It is the average number of years an infant is supposed to live } \\
\text { having been exposed to age specific mortality rates at certain } \\
\text { periods all through his/her life (TÜIK, 2015). }\end{array}$ & Ratio & World Bank \\
\hline Unemployment $(\log )$ & Annual unemployment rate. & Ratio & World Bank \\
\hline GDP growth $(\log )$ & Annual growth rate for GDP. & Ratio & World Bank \\
\hline $\begin{array}{l}\text { Internet users (per } \\
100 \text { people) }\end{array}$ & $\begin{array}{l}\text { Internet users are individuals who have used the Internet } \\
\text { (from any location) in the last } 12 \text { months. Internet can be } \\
\text { used via a computer, mobile phone, personal digital assistant, } \\
\text { games machine, digital TV etc. }\end{array}$ & Ratio & World Bank \\
\hline $\begin{array}{l}\text { Corruption Perception } \\
\text { Index (CPI) }\end{array}$ & $\begin{array}{l}\text { CPI Score relates to perceptions of the degree of corruption } \\
\text { as seen by business people, risk analysts and the general } \\
\text { public, and ranges between } 10 \text { (highly clean) and } 0 \text { (highly } \\
\text { corrupt). }\end{array}$ & Ratio & $\begin{array}{l}\text { Transparency } \\
\text { International }\end{array}$ \\
\hline $\begin{array}{l}\text { Human Development } \\
\text { Index (HDI) }\end{array}$ & $\begin{array}{l}\text { HDI is a composite indicator of life expectancy, education, } \\
\text { and income per capita indicators, which are used to rank } \\
\text { countries (between } 0-1 \text { ) }\end{array}$ & Ratio & $\begin{array}{l}\text { United Nations } \\
\text { Development } \\
\text { Program }\end{array}$ \\
\hline Environment & Environmental Wellbeing Scores & Ratio & $\begin{array}{l}\text { Sustainable } \\
\text { Society } \\
\text { Foundation } \\
\end{array}$ \\
\hline Political rights & \multirow{2}{*}{$\begin{array}{l}\text { The political rights questions are grouped into three } \\
\text { subcategories: Electoral Process, Political Pluralism and } \\
\text { Participation, and Functioning of Government (scores } \\
\text { between 0-40). The civil liberties questions are grouped into } \\
\text { four subcategories: Freedom of Expression and Belief, } \\
\text { Associational and Organizational Rights, Rule of Law, and } \\
\text { Personal Autonomy and Individual Rights (scores between 0- } \\
\text { 60). A country or territory is assigned two ratings ( } 7 \text { to 1) one } \\
\text { for political rights and one for civil liberties. }\end{array}$} & Categorical & $\begin{array}{l}\text { Freedom } \\
\text { House } \\
\text { Organization } \\
\end{array}$ \\
\hline Civil liberties & & Categorical & $\begin{array}{l}\text { Freedom } \\
\text { House } \\
\text { Organization }\end{array}$ \\
\hline $\begin{array}{l}\text { Vanhanen's } \\
\text { democracy index }\end{array}$ & $\begin{array}{l}\text { Developed by Tatu Vanhanen in early 1970s } \\
\text { Competition and Participation. Both are calculated using } \\
\text { election data, and the democracy index is estimated by } \\
\text { combining the two. Competition: the percentage share of the } \\
\text { smaller parties and independents of votes cast in } \\
\text { parliamentary elections, or of the seats in parliament } \\
\text { Participation: the percentage of population that voted in } \\
\text { elections }\end{array}$ & Ratio & $\begin{array}{l}\text { Finnish Social } \\
\text { Science Data } \\
\text { Archive (FSD) }\end{array}$ \\
\hline Polity score & $\begin{array}{l}\text { (polity } 2 \text { variable) The "Polity Score" captures this regime } \\
\text { authority spectrum on a } 21 \text {-pont scale ranging from }-10 \\
\text { (hereditary monarchy) to }+10 \text { (consolidated democracy). The } \\
\text { Polity scores can also be converted into regime categories in } \\
\text { a suggested three-part categorization of "autocracies" }(-10 \text { to } \\
-6) \text {, "anocracies" }(-5 \text { to }+5) \text {, and "democracies" }(+6 \text { to }+10) \text {. }\end{array}$ & Interval & $\begin{array}{l}\text { Center for } \\
\text { Systemic } \\
\text { Peace }\end{array}$ \\
\hline EIU democracy & $\begin{array}{l}\text { The index is based on } 60 \text { indicators grouped in five different } \\
\text { categories measuring pluralism, civil liberties, and political } \\
\text { culture. In addition to a numeric score ((between } 0-10) \text { and a } \\
\text { ranking, the index categorizes countries as one of four regime } \\
\text { types full democracies, flawed democracies, hybrid regimes } \\
\text { and authoritarian regimes. }\end{array}$ & Ratio & $\begin{array}{l}\text { The Economist } \\
\text { Intelligent Unit }\end{array}$ \\
\hline
\end{tabular}

Table 2. Data Features and Resources 


\subsection{Comparison of Government Systems Using Principal Component Analysis}

Principal component analysis is one of the earliest multivariate analysis techniques which was firstly used by Pearson in 1901 and developed by Hotelling in 1933. It reduces the dimensionality of multivariate data while preserving as much of the relevant information as possible. It transforms the dataset of a large number of interrelated variables to uncorrelated dataset with less variables.

Data set for principal component analysis consists of various indicators of countries i.e. population, GDP, GDP per capita, life expectancy at birth, internet users, corruption perception, human development, environmental wellbeing, political rights, civil liberties, Vanhanen's democracy index, polity and EIU democracy scores. Analysis was performed by using SPSS version 23 (IBM Corp., 2015). First of all Kaiser-Meyer-Olkin (KMO) and Barttlett's test of sphericity were applied measures of sampling adequacy for principal component analysis. KMO is expected to be greater than 0.5 for sampling adequacy (Cerny \& Kaiser, 1977). Bartlett's test of sphericity is for the overall significance of all correlations within a correlation matrix (Bartlett, 1950). The test results in Table 3 show that the data set is appropriate for principal component analysis $(\mathrm{KMO}>0.50$ and $\mathrm{P}<0.01)$.

\begin{tabular}{|l|l|l|}
\hline \multicolumn{2}{|l|}{ Kaiser-Meyer-Olkin Measure of Sampling } & 0.789 \\
Adequacy & Approx. Chi-Square & 701.233 \\
\hline $\begin{array}{l}\text { Bartlett's Test of } \\
\text { Sphericity }\end{array}$ & df (degree of freedom) & 78 \\
\hline & $\begin{array}{l}\text { Significance } \\
\text { probability }\end{array}$ & 0.000 \\
\hline
\end{tabular}

Table 3. KMO Measure and Bartlett's Test of Sphericity

Number of variables in data set was reduced to three components providing meaningful information. These three dimensions were named "democracy," "development" and "structural size" in accordance with the content variables. Countries were compared with respect to these new components. Component matrix is shown in Table 4.

Rotated Component Matrix ${ }^{\mathrm{a}}$

\begin{tabular}{|l|l|l|l|}
\hline \multicolumn{2}{|l|}{} & \multicolumn{2}{|l|}{ Component } \\
\cline { 2 - 4 } & 1 (Democracy) & 2 (Development) & 3 (Structural Size) \\
\hline Population & 0.011 & -0.128 & $\mathbf{0 . 9 3 8}$ \\
GDP (constant \$) & 0.038 & 0.269 & $\mathbf{0 . 9 0 6}$ \\
GDP per capita (current \$) & 0.237 & $\mathbf{0 . 8 9 4}$ & 0.150 \\
Life expectancy at birth & 0.525 & $\mathbf{0 . 6 2 9}$ & -0.065 \\
Internet users & 0.218 & $\mathbf{0 . 8 7 6}$ & -0.037 \\
Corruption perception & 0.636 & $\mathbf{0 . 6 0 3}$ & -0.099 \\
Human development & 0.226 & $\mathbf{0 . 9 2 6}$ & 0.041 \\
Environmental well-being & 0.424 & $\mathbf{- 0 . 6 5 0}$ & -0.179 \\
Political rights & $\mathbf{- 0 . 9 2 7}$ & -0.184 & 0.059 \\
Civil liberties & $\mathbf{- 0 . 9 0 6}$ & -0.300 & 0.115 \\
Vanhanen democracy & $\mathbf{0 . 6 4 3}$ & 0.145 & 0.206 \\
PolityIV score (polity2) & $\mathbf{0 . 9 4 4}$ & -0.044 & 0.028 \\
EIU democracy & $\mathbf{0 . 9 2 8}$ & 0.196 & 0.055 \\
\hline
\end{tabular}

Extraction Method: Principal Component Analysis.

Rotation Method: Varimax with Kaiser Normalization.

a. Rotation converged in 5 iterations.

Component Transformation Matrix

\begin{tabular}{|l|l|l|l|}
\hline Component & 1 (Democracy) & 2 (Development) & 3 (Structural Size) \\
\hline 1 (Democracy) & 0.796 & 0.605 & 0.031 \\
\hline 2 (Development) & -0.587 & 0.758 & 0.286 \\
\hline 3 (Structural Size) & 0.150 & -0.245 & 0.958 \\
\hline
\end{tabular}

Extraction Method: Principal Component Analysis.

Rotation Method: Varimax with Kaiser Normalization.

\section{Table 4. Principal Components and Transformation Matrix}

Principal components analysis provided composite scores of countries for these new factors to use in comparisons. The countries were sorted by scores for each component. In terms of development component, most 
developed countries in the first places are South Korea is presidential; Slovenia is semi-presidential and Estonia is a parliamentary democracy. Nicaragua, the Philippines, Guatemala, Indonesia, Honduras, Bolivia, El Salvador and Paraguay as the countries with lower socioeconomic development scores, are governed by presidential systems. But the lowest score belongs to Papua New Guinea, which is a parliamentary system. In terms of democracy component, the results show that low scores are observed in presidential and president-parliamentary systems. Turkmenistan, Uzbekistan with presidential systems and Belarus, Kazakhstan, Azerbaijan and Russia ruled by president-parliamentary system have lower scores. On the other hand, there are four presidential systems (Costa Rica, Uruguay, Chile and Panama), five semi-presidential systems (Slovenia, the Czech Republic, Lithuania, Slovakia and Poland) and one parliamentary system (Hungary) among the 10 highest scores of democracy component. It should be remembered that the number of countries with parliamentary systems is less in the scope of study. Even so, there are good examples in terms of democracy and development.

Results show that countries vary according to government systems in terms of better development and democracy indicators. But the reservation can be made for the president-parliamentary systems in terms of democracy scores, four out of six countries have the lower values. And it is also striking that these countries have very high economic development level relatively depending on national resources.

\subsection{Comparison of Government Systems Using Panel Data Analysis}

Panel data is a dataset in which the behavior of entities (individuals, countries, provinces, companies etc.) is observed across time. Panel data analysis is used to make inferences about relationships among the variables considering changes over time. Even though panel data analysis is based on earlier theoretical work, practical work began in the 1990s depending on advances in computer and software technology. The literature on panel data analysis has developed rapidly and it is increasingly being used as its advantages over cross-sectional analysis.

In this study, panel data covers annual data of 53 countries for the period 1995-2013. Panel data analysis was performed using STATA software version 14 (StataCorp., 2015). First of all, stationarity was tested, which is an important assumption in time series. Stationary series wander up and down around of horizontal line indicating the mean of the series, without any consistent trend (upward or downward) over the entire time span. The use of non-stationary series can produce invalid estimates yielding deceptive relationships actually without meaning. Panel unit root tests (Im, Pesaran \& Shin, 2003) were performed to check the stationary properties of the variables. According to results, population, GDP per capita and unemployment rate are non-stationary series while growth rate, life expectancy and democracy scores are stationary. First differences of the non-stationary series are stationary and they were used in the panel data. Generalized linear latent and mixed models (gllamm) which is a STATA command independently developed by Rabe-Hesketh, Skrondal \& Pickles $(2002,2005)$ were used in the analysis. The model allows using unordered categorical independent variables. The degree of the relationships between government systems and development or and democracy in the long run can be analyzed.

In the first model, population, GDP per capita, unemployment rate, growth rate, life expectancy at birth and Polity score for democracy were the independent variable. The choice of variables was made on the basis of data availability for balanced panel, considering pairwise correlations and results of principal component analysis. The estimation by using GLAMM shows that there is no significant relationship between government systems and economic development indicators i.e. GDP per capita, unemployment rate and growth rate. Population, life expectancy and Polity scores are significant variables in the model. The results of estimation were given in Table 5 .

The second model is the simplified one and covers GDP per capita, life expectancy at birth and Polity score. The results were obtained in the same direction (Table 6). When Vanhanen competition index, instead of Polity scores, was used in the model, the relationship between Vanhanen competition index and development are not significant. Polity score represents a wider definition of democracy that is directly or indirectly is affected by the other socioeconomic indicators. Vanhanen index stands for a narrower idea of democracy. Insignificant relationship means political participation and competition differ in each government systems.

\begin{tabular}{|ll|l|l|l|}
\hline \multicolumn{5}{|l|}{ Government system (dependent variable) } \\
\hline Independent variables & & Coefficients & $\begin{array}{l}\text { Significance } \\
\text { probability }\end{array}$ & \\
\hline Population & $(\mathrm{ln}, 1$. diff.) & -62.1231 & 0.000 & significant at the 1\% level \\
\hline GDP per capita & $(\mathrm{ln}, 1$. diff $)$ & 0.3036 & 0.405 & - \\
\hline Unemployment rate & $(\mathrm{ln}, 1$. diff $)$ & -0.2200 & 0.383 & - \\
\hline Growth rate & $(\mathrm{ln})$ & 0.0882 & 0.862 & - \\
\hline Life expectancy at birth & $(\mathrm{ln})$ & -2.8671 & 0.000 & significant at the 1\% level \\
\hline Democracy score & Polity score & 0.0302 & 0.019 & significant at the 5\% level \\
\hline Constant & 14.5845 & 0.000 & significant at the 1\% level \\
\hline $\begin{array}{l}\text { log likelihood = -1139.2938 } \\
\text { Variance (at level 1) } 0.9610409(0.0478178)\end{array}$ & & \\
\hline
\end{tabular}

Table 5. Panel Data Model (GLAMM 1) 


\begin{tabular}{|ll|l|l|l|}
\hline \multicolumn{5}{|c|}{ Government system (dependent variable) } \\
\hline Independent variables & Coefficients & $\begin{array}{l}\text { Significance } \\
\text { probability }\end{array}$ & \\
\hline Population & $(\ln , 1$. diff.) & -59.7538 & 0.000 & significant at the 1\% level \\
\hline GDP per capita & $(\ln , 1$. diff.) & 0.0689 & 0.776 & - \\
\hline Life expectancy at birth & $(\ln )$ & -3.5883 & 0.000 & significant at the 1\% level \\
\hline Democracy score & Polity score & 0.0300 & 0.038 & significant at the 5\% level \\
\hline Constant & 17.7051 & 0.000 & significant at the 1\% level \\
\hline $\begin{array}{l}\text { log likelihood = -1331.1841 } \\
\text { Variance (at level 1) 1.0053(0.04667) }\end{array}$ & \\
\hline
\end{tabular}

Table 6. Panel Data Model (GLAMM 2)

In order to compare results, the analysis was repeated with a binary logistic panel model for each government systems (binary - xtlogit). Three models were established with the variables in the simplified model above. In binary models categorical variable is equal to 1 if a country's system is presidential and to 0 otherwise. Models were created for semi-presidential and parliamentary systems likewise. The results from Hausman test is in favor of random effects model. The test results and significance probabilities are shown in Table 7.

\begin{tabular}{|c|c|c|c|}
\hline & \multicolumn{3}{|c|}{ Dependent variables (binomial) } \\
\hline & Presidential (1) & Semi-presidential (1) & Parliamentary (1) \\
\hline Independent variables & \multicolumn{3}{|c|}{ Significance probability $(\mathrm{p})$} \\
\hline Population & 0.021 & 0.002 & 0.201 \\
\hline GDP per capita & 0.987 & 0.127 & 0.121 \\
\hline Life expectancy at birth & 0.051 & 0.099 & 0.949 \\
\hline Democracy score & 0.323 & 0.001 & 0.000 \\
\hline Constant & 0.041 & 0.092 & 0.000 \\
\hline $\begin{array}{l}\text { Hausman Test } \quad \text { chi2(4) } \\
\text { p }\end{array}$ & - & $\begin{array}{l}5.06 \\
0.2812 \\
\end{array}$ & $\begin{array}{l}4,13 \\
0.3891\end{array}$ \\
\hline \multirow[t]{4}{*}{ Model } & Random effects & Random effects & Random effects \\
\hline & Waldchi2 $2(4)=8.38$ & Wald chi2 $(4)=19.26$ & Wald chi2 $(4)=53.76$ \\
\hline & Prob $>$ chi $2=0.0785$ & Prob $>$ chi $2=0.0007$ & Prob $>$ chi $2=0.0000$ \\
\hline & $\begin{array}{l}\text { Model is significant at } \\
\text { the } 10 \% \text { level }\end{array}$ & $\begin{array}{l}\text { Model is significant at } \\
\text { the } 1 \% \text { level }\end{array}$ & $\begin{array}{l}\text { Model is significant at } \\
\text { the } 1 \% \text { level }\end{array}$ \\
\hline
\end{tabular}

Table 7. Panel Data Model (binary - xtlogit)

According to the logistic model, presidential systems vary for different level of socioeconomic indicators, only population has impact on the presidential systems since they are common in more populated countries. The effect of democracy scores is significant in semi-presidential systems and parliamentary systems. Here it is understood that democracy impact on government systems comes from the president-parliamentary systems positioned in semi-presidential group. The results also show that GDP per capita and life expectancy at birth, which are among the elements of human development index, have no significant relationship with government systems at the 5\% level. Accordingly, government systems cannot be explained by the level of economic development.

Finally, the relationship between development and democracy were analyzed by using the panel data method. Three models were defined for different dependent variables. Government systems are used as categorical independent variable in each model. Fixed effects model was preferred in analysis according to Hausman test. The results shown in Table 8 are in accordance with the previous results in terms of government systems. GDP per capita is not explained by government systems. Government systems have a significant impact on life expectancy at birth and democracy scores.

In the context of the relationship between democracy and development, the results are not straightforward to establish such causality. The two development indicators (i.e. GDP per capita and life expectancy) and government systems have significant impact on the polity scores. Similarly the polity scores have a positive impact on both development indicators.

When Vanhanen competition index was used instead of Polity scores, the relationship between democracy and development is not significant, similar to the previous model. The two development indicators (i.e. GDP per capita and life expectancy) and government systems have no impact on the competition in the country. Actually the model is statistically insignificant (Table 9). 


\begin{tabular}{|l|l|l|l|}
\hline \multirow{2}{*}{ Independent variables } & Dependent variables \\
\cline { 2 - 4 } & GDP per capita & Life expectancy at birth & Democracy (Polity) \\
\hline GDP per capita & & $0.0172(0.001)$ & $0.8493(0.037)$ \\
\hline Life expectancy at birth & $0.7374(0.001)$ & & $13.5572(0.000)$ \\
\hline Democracy (Polity) & $0.0058(0.037)$ & $0.0022(0.000)$ & \\
\hline Government system & $0.0145(0.605)$ & $0.0132(0.002)$ & $1.9114(0.000)$ \\
\hline Constant & $-3.1417(0.001)$ & $4.2250(0.000)$ & $-56.1085(0.000)$ \\
\hline Hausman Test chi2 $(\mathrm{p})$ & $26.00(0.000)$ & $9.30(0.026)$ & $17.07(0.007)$ \\
\hline Model & Fixed effects & Fixed effects & Fixed effects \\
\hline & $\mathrm{F}(3,878)=7.00$ & $\mathrm{~F}(3,878)=20.48$ & $\mathrm{~F}(3,878)=26.27$ \\
\hline & Prob $>\mathrm{F}=0.0001$ & Prob $>\mathrm{F}=0.0000$ & Prob $>\mathrm{F}=0.000$ \\
\hline & $\begin{array}{l}\text { Model is significant at } \\
\text { the 1\% level }\end{array}$ & $\begin{array}{l}\text { Model is significant at } \\
\text { the 1\% level }\end{array}$ & $\begin{array}{l}\text { Model is significant at } \\
\text { the 1\% level }\end{array}$ \\
\hline
\end{tabular}

Table 8. Panel Data Model for Development and Democracy (Polity scores)

\begin{tabular}{|l|l|l|l|}
\hline \multirow{2}{*}{ Independent variables } & Dependent variables & \multicolumn{2}{|l|}{} \\
\cline { 2 - 4 } & GDP per capita & $\begin{array}{l}\text { Life expectancy at } \\
\text { birth }\end{array}$ & Democracy(Vanhanen) \\
\hline GDP per capita & & $0.0197(0.000)$ & $1.3033(0.499)$ \\
\hline Life expectancy at birth & $0.8251(0.000)$ & & $-13.4661(0.281)$ \\
\hline Democracy (Vanhanen) & $0.0004(0.499)$ & $-0.0000(0.281)$ & \\
\hline Government system & $0.0253(0.358)$ & $0.0179(0.000)$ & $0.9094(0.563)$ \\
\hline Constant & $-3.5241(0.000)$ & $4.2322(0.000)$ & $103.823(0.050)$ \\
\hline Hausman Test chi2 $(\mathrm{p})$ & $19.97(0.000)$ & $60.68(0.000)$ & $8.23(0.0415)$ \\
\hline Model & Fixed effects & Fixed effects & Fixed effects \\
\hline & $\mathrm{F}(3,878)=5.68$ & $\mathrm{~F}(3,878)=11.74$ & $\mathrm{~F}(3,878)=0.56$ \\
\hline & Prob $>\mathrm{F}=0.0007$ & Prob $>\mathrm{F}=0.0000$ & Prob $>\mathrm{F}=0.6436$ \\
\hline & $\begin{array}{l}\text { Model is significant at } \\
\text { the 1\% level }\end{array}$ & $\begin{array}{l}\text { Model is significant at } \\
\text { the 1\% level }\end{array}$ & Model is insignificant \\
\hline
\end{tabular}

Table 9. Panel Data Model for Development and Democracy (Vanhanen)

\section{Conclusions}

In this study, the relationship between socioeconomic development level and government systems of countries was examined. The different techniques show that evaluations related to the presence of such relationship seem to be meaningless. As stated by Bernhard et al. (2001), Cheibub \& Limongi, (2002) and Siaroff (2003), diversity in the practices makes the conceptual categories useless in terms of government systems. The variation within decision making processes in each category prevents making comparisons with general definitive classifications. In other respects, authoritarian or imperial histories of countries, managements of natural resources and correspondingly socio-cultural environments are variables which are mostly difficult to measure and include in the model.

On the other hand, democracy scores and government systems have an impact on each other in panel analysis. It is also a conceptional issue from several perspectives. Democracy with a narrower definition, which is represented by competition of more than one political party, does not have an impact on neither development nor government systems. The significant relationship between democracy in a wider concept and government systems is due to relatively small number of president-parliamentary systems and parliamentary systems in the scope have homogeneous scores in terms of democracy. Presidential systems vary according to democracy level.

As a frequently discussed topic, the relationship between development and democracy is a derivative subject in the study. Development indicators and wider conception of democracy are closely related, because this conceptional approach counts that level of democracy is also one of components of development.

\section{References}

- Bartlett, M. (1950). “Tests of Significance in Factor Analysis”. British Journal of Statistical Psychology, 3 (2), 77-85.

- Bernhard, M., Nordstrom, T. \& Reenock, C. (2001). "Economic performance, institutional intermediation, and democratic survival". Journal of Politics , 63 (3), 775-803.

- Center For Systemic Peace (2015). The Polity Project, Polity Score. http://www.systemicpeace.org/inscrdata.html (1.11. 2015) 
- Cerny, C. \& Kaiser, H. (1977). "A study of a measure of sampling adequacy for factor-analytic correlation matrices”. Multivariate Behavioral Research, 12 (1), 43-47.

- Cheibub, J. A. \& Limongi, F. (2002). "Democratic Institutions And Regime Survival: Parliamentary and Presidential Democracies Reconsidered”. Annual Review Political Science , 5, 151-79.

- Cutright, P. (1963). "National political development: Measurement and analysis". American Sociological Review, 28, 253-264.

- Doğan, A. (2005). "Demokrasi ve ekonomik gelişme”. Erciyes Üniversitesi İktisadi ve İdari Bilimler Fakültesi Dergisi (25), 1-19.

- $\quad$ Elgie, R. \& Schleiter, P. (2009). 'Variation in the durability of semi-presidential democracies'. In Conference of 21st World Congress of International Political Science Association. (8.3.2015) http://paperroom.ipsa.org/papers/paper_2514.pdf.

- Elgie, R. (1999). The Politics of Semi-Presidentialism. R. Elgie (Ed.) Semi-Presidentialism in Europe (s. 1-21). Oxford: Oxford University Press.

- Elgie, R. (2005). “From Linz to Tsebelis: three waves of presidential/parliamentary studies?”. Democratization , 12 (1), 106-122.

- Elgie, R. (2015). Semi presidentialism: http://www.semipresidentialism.com (10.12.2015)

- $\quad$ Finnish Social Science Data Archive (2015). Vanhanen Demokrasi Endeksi. Finnish Social Science Data Archive (FSD): http://www.fsd.uta.fi/en/ (10.3.2015)

- $\quad$ Freedom House Organization (2015). Freedom In The World 2015. https://freedomhouse.org/report/freedom-world-2015/methodology (10.10.2015)

- Gönenç, L. (2007). "Hükümet Sistemi Tartışmalarında Başkanlı Parlamenter Hükümet Sistemi Seçeneği”. Güncel Hukuk, 44, 39-43 (10.3.2015) . http://www.yasayananayasa.ankara.edu.tr/belgeler/makaleler/baskanli_parlamenter_sistem.pdf

- IBMCorp. (2015). IBM SPSS Statistics for Windows, Version 23.0. Armonk, NY: IBM Corp.

- Im, K., Pesaran, H. \& Shin, Y. (2003). “Testing for Unit Roots in Heterogenous Panels”. Journal of Econometrics , 115 (1), 53-74.

- Jackman, R. W. (1973). "On the Relation of Economic Development to Democratic Performance". American Journal of Political Science , 17 (3), 611-21.

- Jones, M. P. (1995). Electoral laws and the survival of presidential democracies. Notre Dame: University of Notre Dame Press.

- Lijphart, A. (1991). "Constitutional choices for new democracies". Journal of Democracy, 2(1), 72-84.

- Linz, J. J. (1978). The Breakdown of Democratic Regimes. J. Linz \& A. Stepan (Ed.) içinde, The Breakdown of Democratic Regimes: Crisis, Breakdown, and Reequilibration (s. 3-124). Baltimore: The John Hopkins University Press.

- Linz, J. J. (1990). “The Perils of Presidentialism”. Journal of Democracy, 1(1). s. 51-69.

- Linz, J. J. (1990). “The Virtues of Parliamentarism”. Journal of Democracy, 1(4). 84-91.

- $\quad$ Lipset, S. S. (1959). "Some social requisites of democracy: Economic development and political legitimacy”. The American Political Science Review , 53 (1), 69-105.

- Mainwaring, S. \& Scully, T. (1995). Building Democratic Institutions: Party Systems in Latin America. Stanford: Stanford University Press.

- Neubauer, D. (1967). "Some Conditions of Democracy”. American Political Science Review , 61 (4), $1002-$ 9.

- Przeworski, A. \& Limongi, F. (1997). “Modernization, Theories and Facts". World Politics, 49(2): $155-83$.

- Przeworski, A. (2004). Democracy and Economic Development. E. D. Mansfield \& R. Sisson (Ed.), Political Science and the Public Interest. Columbus: Ohio State University Press.

- Przeworski, A., Alvarez, M. E., Cheibub, J. A. \& Limongi, F. (2000). Democracy and Development: Political Institutions and Well-Being in the World, 1950-1990. Cambridge University Press.

- Przeworski, A., Alvarez, M., Cheibub J. A. \& Limongi F. (1996). "What Makes Democracy Endure?" Journal of Democracy, 7(1): 39-55.

- $\quad$ Rabe-Hesketh, S., Skrondal, A. \& Pickles, A. (2005). "Maximum likelihood estimation of limited and discrete dependent variable models with nested random effects". Journal of Econometrics , 128 (2), 301323. 
- $\quad$ Rabe-Hesketh, S., Skrondal, A. \& Pickles, S. (2002). "Reliable estimation of general linear mixed models using adaptive quadrature”. The Stata Journal , 1, 1-21.

- Sayarı, S. \& Dikici Bilgin, H. (2013). Karşılaştırmalı Siyaset. İstanbul Bilgi Üniversitesi Yayınları.

- Shugart, M. (2005). "Semi-presidential systems: Dual executive and mixed authority patterns". French Politics , 3 (3), 323-351.

- $\quad$ Shugart, M. S. \& Carey, J. M. (1992). Presidents and assemblies: Constitutional design and electoral dynamics. Cambridge University Press.

- $\quad$ Siaroff, A. (2003). "Comparative presidencies: The inadequacy of the presidential, semi-presidential and parliamentary distinction”. European Journal of Political Research, 42 (3), 287-312.

- StataCorp. (2015). Stata Statistical Software: Release 14. College Station, TX: StataCorp LP.

- $\quad$ Stepan, A. \& Skach, C. (1993). "Constitutional frameworks and democratic consolidation: Parliamentarianism versus presidentialism”. World Politics, 46 (01), 1-22.

- Sustainable Society Foundation (2015). Environmental Wellbeing Index Scores. http://www.ssfindex.com/ssi/ (1.11. 2015)

- The Economist Intelligence Unit (EIU) (2015). Democracy Index 2014. http://www.eiu.com/ (1.11. 2015).

- Transparency International (2015). Corruption Perception Index (Yolsuzluk Alg1sı Endeksi). https://www.transparency.org/research/cpi/cpi_early (1.11.2015)

- TurkStat (Turkish Statistical Institution) (2015). Metadata of Life Tables (Hayat Tabloları Metaverisi). http://www.turkstat.gov.tr/PreTablo.do?alt_id=1100 (1.5.2016)

- $\quad$ United Nations Development Programme (UNDP) (2015). Human Development Index. (1.11.2015) http://hdr.undp.org/en/content/exporting-data-and-understanding-api

- Yücel, B. (2003). "Yarı-Başkanlık Sisteminin Hükümet Modeli Üzerine Karşılaştırmalı Bir Çalışma: Fransa Modeli ve Komünizm Sonrası Polonya.” AÜHFD, 52 (4), 335-364. 